\title{
Geochemical Studies
}

in the Southwestern

Wisconsin Zinc-Lead

Area

GEOLOGICAL SURVEY BULLETIN 10 OOA-E

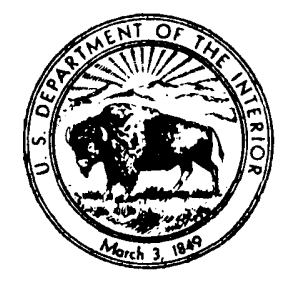




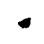

$-$ 4

$+$

$\Delta$

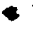

4

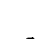

-

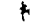

$-$

4

4

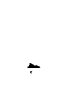

$+$

$+$ 


\title{
- A CONTRIBUTION TO GEOCHEMICAL PROSPECTING FOR MINERALS
}

\author{
GEOCHEMICAL STUDIES IN THE SOUTHWESTERN \\ WISCONSIN ZINC-LEAD AREA
}

\author{
By Vance C. Kennedy
}

ABSTRACT

Samples of natural water, soils, and rocks were collected in the southwestern Wisconsin zinc-lead area and analyzed for lead, zinc, and "total heavy metals" (undifferentiated lead, zinc, and copper). The purpose of the study was to determine whether known geochemical techniques might be of use in searching for ores in this mining district.

Anomalously high concentrations of lead and zinc were found in unweathered rock and in undisturbed residuum in the vicinity of known deposits of lead and zinc. In addition, streams draining areas known to contain lead and zinc minerals were found to contain unusually high quantities of heavy metals (mainly zinc) in solution.

The data indicate that geochemical prospecting techniques should be of value in the search for ore in the southwestern Wisconsin zinc-lead area.

\section{INTRODUCTION}

This report describes the work done and the results obtained during a study of the distribution of zinc and lead in soils, rocks, and natural waters of the southwestern Wisconsin zinc-lead area.

The study was begun on the recommendation of A. V. Heyl, Jr., of the U. S. Geological Survey who suggested that an investigation be made of the applicability of geochemical prospecting techniques in southwestern Wisconsin. Field work begun in 1947 by Lyman C. Huff was continued under the direction of the writer during the following three summers.

The data of Huff's preliminary investigation showed pronounced variations in the quantity of heavy metals (undifferentiated zinc, lead, and copper) in solution in spring, stream, and mine waters in the vicinity of Potosi, Wis. The study of waters near Potosi was continued during the summer of 1948 and was completed by the writer in the spring of 1950 .

4 Sampling of soils and rocks was begun by the writer in 1948 and continued into 1950. This work included a study of the loess in some 
parts of the mining district, and of the distribution of metals in soil, rock, and ground water adjacent to known ore deposits.

In the course of these studies, the writer received help from individuals, employees of several mining companies, and from members of both the U. S. Geological Survey and U. S. Bureau of Mines. Robert R. Reynolds and Harold B. Ewoldt of Calumet and Hecla Consolidated Copper Company, O. E. Dewitt of the Vinegar Hill Zinc Company, and William Singer of the Dodgeville Mining Company all supplied information. Will Andrews, owner of the property at Crow Branch, kindly gave permission for the detailed work done at Crow Branch and supplied information about past mining activity there. The Wisconsin Institute of Technology provided laboratory space and some laboratory equipment. A. V. Heyl, Jr., E. J. Lyons, and A. F. Agnew of the U. S. Geological Survey supplied information concerning the local geology and made valuable suggestions regarding the conduct of the work. John W. Allingham, also of the U. S. Geological Survey, collected and identified some of the sample rock cuttings from churn-drill holes. Wesley A. Grosh, Bureau of Mines engineer, supplied information regarding mineralization at both the Champion and Crawford properties, and assisted in the collection of samples at the Crawford property.

John F. Mink in 1949 and Victor J. Kling in 1950 were field assistants. Harold Bloom and $\mathrm{H}$. E. Crowe made the quantitative analyses, and H. E. Crowe, A. P. Marranzino, J. H. McCarthy, and J. P. Schuch made most of the rapid semiquantitative analyses recorded here.

\section{PURPOSE OF INVESTIGATION}

Geochemical methods of prospecting for minerals depend on the existence of unusual quantities of certain elements in material either genetically related to or derived from hidden ore deposits. If the distribution of some element forms a diagnostic pattern either in the unweathered bedrock or in the various types of weathering products, then the systematic collection and chemical analysis of large numbers of samples may help in selecting sites for intensive exploration.

Chemical dispersion patterns indicative of mineral deposits, commonly known as geochemical anomalies or halos, fall naturally into two groups: primary and secondary. A primary anomaly includes all the effects of dispersion of elements into the rocks surrounding or overlying the mineral deposit, presumably by the same mineralizing solutions that were responsible for ore deposition. It is a bedrock feature, unrelated to the present erosion surface. The primary anomaly frequently forms a pattern surrounding the ore which, in crosssection, may resemble a halo. Hence, it has become a common prac- 
tice to refer to the pattern in the rock enclosing an ore deposit-and containing an anomalous concentration of elements related to the deposition of the ores-as a halo even though it may have a very irregular form. Secondary anomalies are the distribution patterns of elements resulting from the weathering either of the ore.body itself or of its associated primary halo. For a discussion of the principles and application of geochemical prospecting methods see Hawkes (1950, p. 537-555) and Harbaugh (1953).

The effectiveness of geochemical prospecting methods in a given district depends on a number of factors, some of which can be determined in advance but most of which must be established by preliminary field experiments in the vicinity of known deposits.

One prerequisite is, of course, the availability of techniques of chemical analysis that provide adequate sensitivity, accuracy, speed, and economy. Chemical procedures suitable for many geochemical prospecting problems have been developed and described by Lakin, Almond, and Ward (1952); some of these were used in obtaining the data for the present report.

The question of what kinds of geochemical anomalies are associated with the ore deposits of the southwestern Wisconsin area, and whether a systematic search for these anomalies would be helpful in exploration can be answered only by field work. The purpose of the present investigation was to establish by experimental sampling in the vicinity of known deposits the characteristics of any geochemical anomalies related to known deposits, the most suitable sampling techniques for detecting and mapping these anomalies, and the kinds of anomalies that are likely to be the most useful in prospecting for new deposits.

\section{TOPOGRAPHY AND GEOLOGY}

The southwestern Wisconsin mining area lies, mostly, in the Driftless Area of midwestern United States (fig. 24). The relief is of the order of 100 to 300 feet, with the greatest relief usually being along the Mississippi River. In general, the topography may be classified as mature.

\section{BEDROCK GEOLOGY}

- The strata consist principally of limestone and cherty dolomite of Ordovician age, with some shale and sandstone (fig. 25). They lie nearly horizontal except for a regional dip to the south of about 18 feet to the mile (Heyl, 1950, p. 14)..$^{2}$ Superimposed on the regional dip is a structural pattern of gently folded anticlines and synclines.

\footnotetext{
1 Heyl, A. V., Jr., 1950, The Upper Mississippi Valley zinc-lead distrlct: U. S. Geol. Survey open-flle rept. 68 .
} 


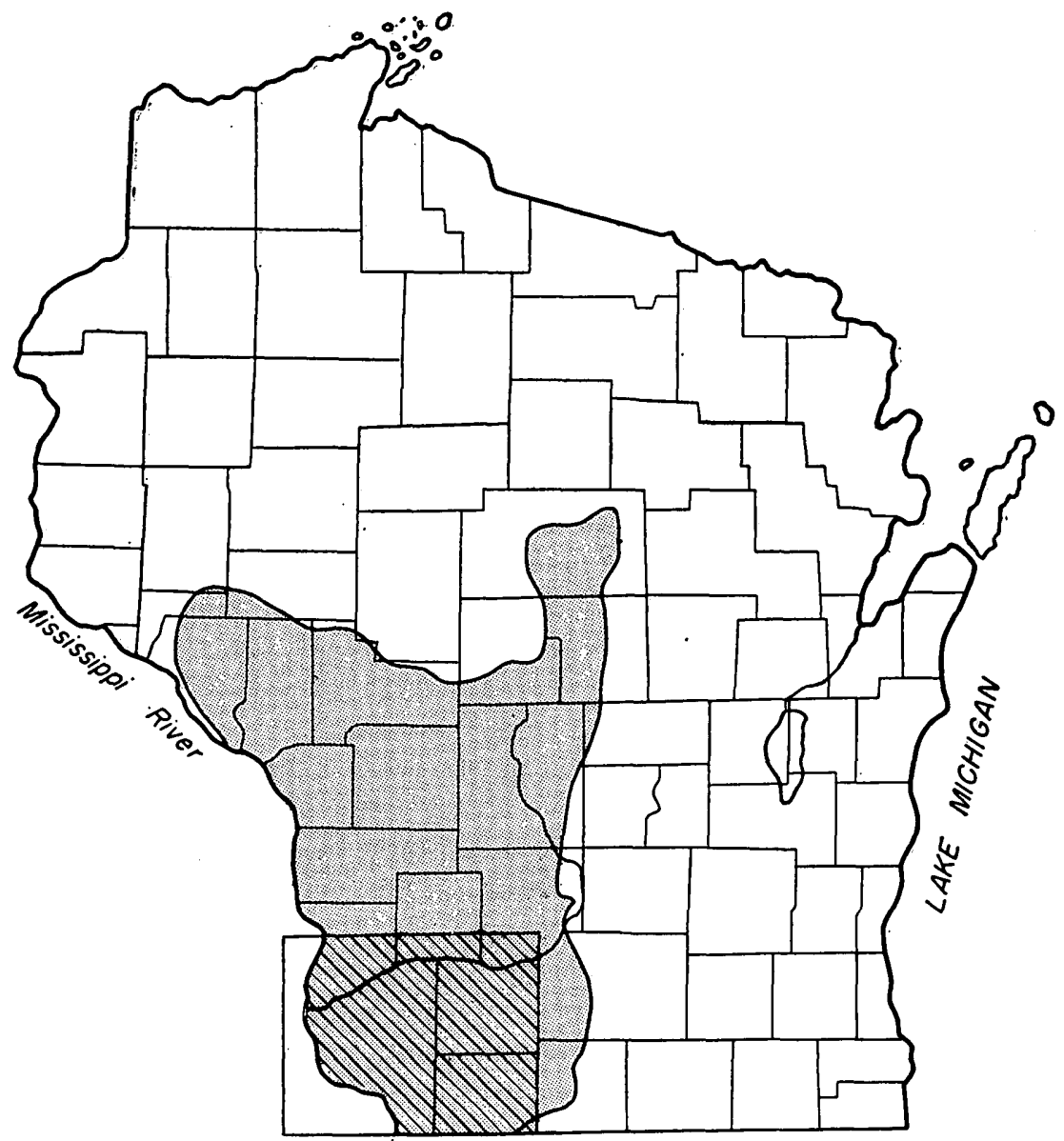

EXPLANATION

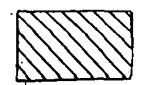

Area shown in detail on figure 27

Driftless area (Bean, 1949)

Fraund 24.-Index map showing boundaries of Driftless Area and of detailed index map (fig. 27).

Behre, Scott, and Banfield (1937, p. 788) state that the detailed structure consists of a series of elliptical basins which are from 1 to 5 miles long and have a length to width ratio ranging from $1: 1$ to $10: 1$. They also say (p. 795) that faulting, both normal and reverse, accompanies the shallow structural basins.

The ore deposits in the area are valuable almost entirely for their zinc and lead content, although a few carloads of copper ore have been shipped from several old prospects in the area. The primary minerals ${ }^{2}$ are ankerite, barite, calcite, chalcopyrite, dolomite, galena, gold, 
marcasite, millerite, pyrite, quartz, sphalerite, wurtzite(?), and an unidentified arsenic-cobalt mineral. Small amounts of cadmium, cobalt, silver, vanadium, germanium, molybdenum, and zirconium have been found in the ores. Principal secondary minerals are chalcocite, greenockite, cuprite, azurite, psilomelane, cerussite, smithsonite, hematite, limonite, malachite, melanterite, and aragonite.

Regarding the structure and stratigraphic occurrence of the ore deposits, Heyl (p. 9-11) says:

The largest number of the zinc deposits occur in the lower part of the Galena dolomite, in the Decorah formation, and in the upper half of the Platteville formation. The crevice-type lead deposits are limited to the Galena dolomite. Small lead, copper, and zinc deposits are found locally along the northern edge of the district in the Prairie du Chien group, and in places the St. Peter sandstone is pyritized directly beneath overlying zinc deposits ***.

The ore deposits are divisible into two major varieties, gash-vein and pitch-

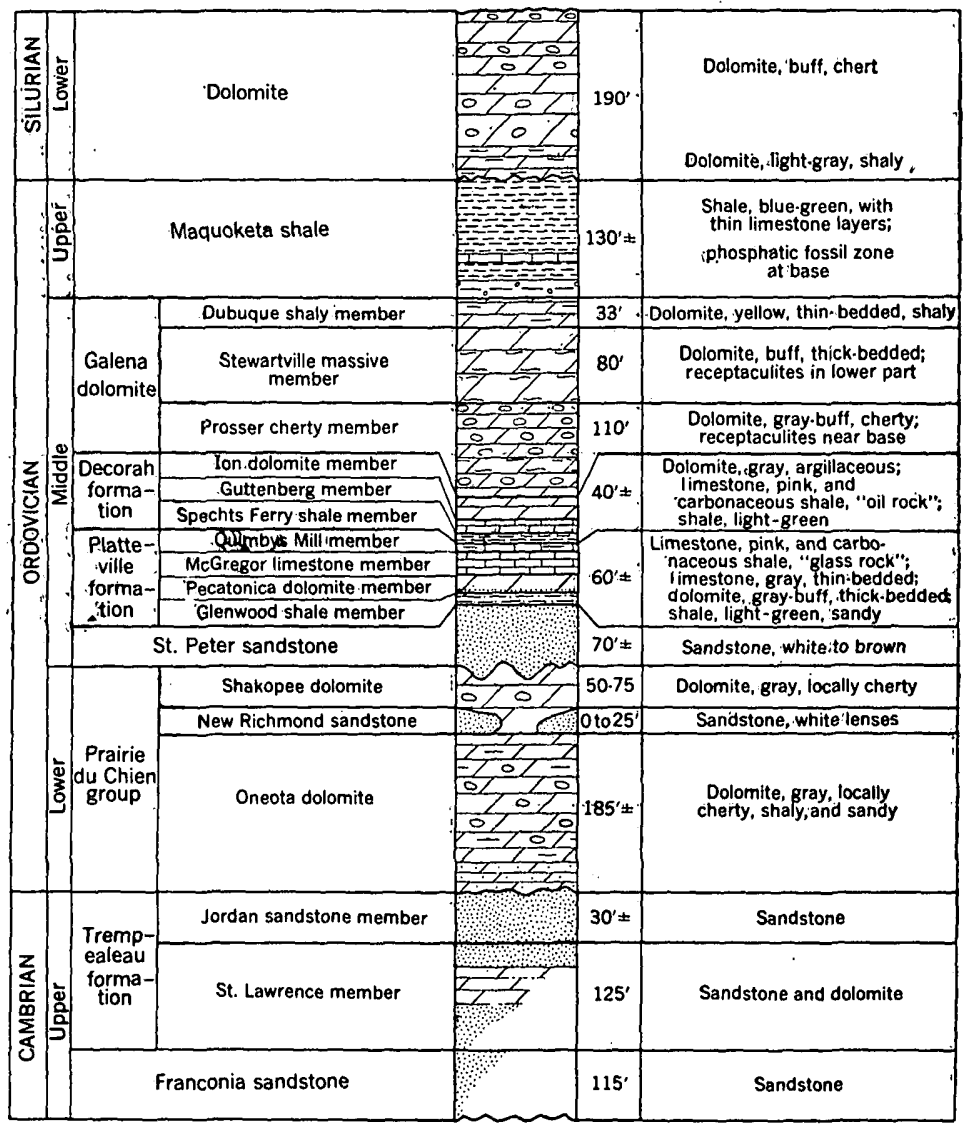

Figora 25.-Generalized stratigraphic section of the Upper Mississippi Valley. zine-lead district (after Heyl and others, 1955). 
and-flat deposits. The gash-vein ${ }^{8}$ deposits contain galena as the principal ore; in the underlying pitch-and-flat deposits, sphalerite is the important ore mineral and galena is a minor mineral. These sphalerite-galena deposits may be further subdivided into the arcuate and the linear type of ore bodies. Figure 3 4 shows the main distinguishing features of these forms of ore bodies, and their stratigraphic relation to one another. In the gash-vein deposits the lead ore is deposited at favorable horizons along vertical joints and in cavities within partially dissolved, brecciated dolomite called "openings." In the underlying pitch-and-flat deposits the zinc-lead ores are banded veins within minor faults and fractures, and also replacements in the bordering rocks along the shear zones.

The stratigraphic units that contain most of the zinc deposits form an escarpment in the northern part of Grant and Iowa Counties (fig. 27) and dip gently southward, so that they are commonly overlain by about 200 feet of rock near the Wisconsin-Illinois border.

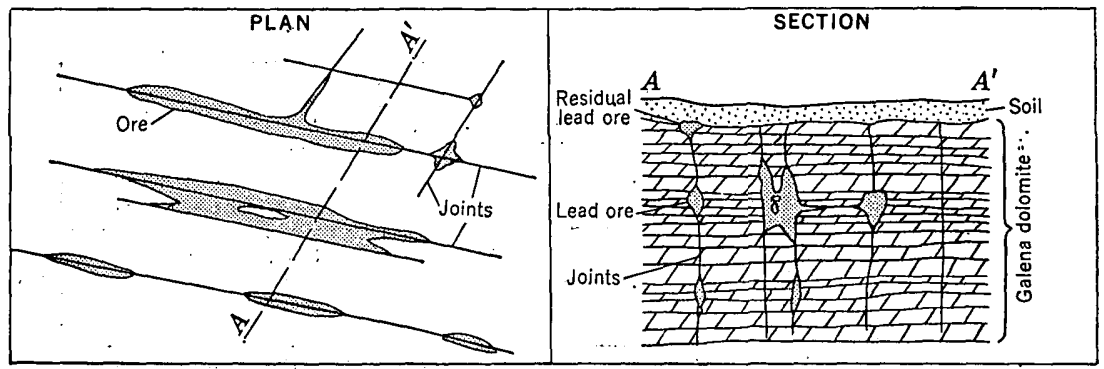

GASH-VEIN DEPOSITS
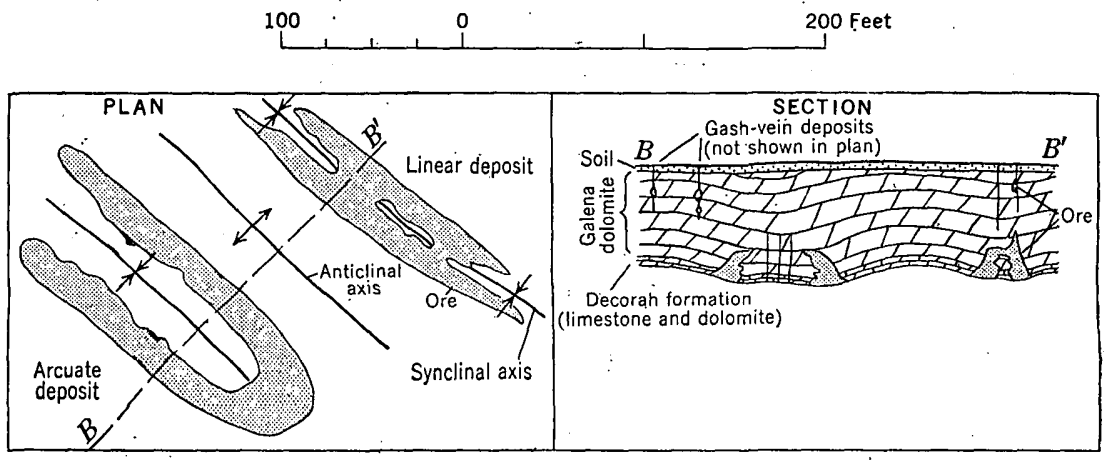

PITCH-AND-FLAT DEPOSITS

400

0

800 Feet

Frovir 26.-Diagrammatic plans and sections llustrating typical patterns of gash-veln lead deposits, and underlying pitch-and-flat zinc deposits of the arcuate and linear types, and their stratigraphic position relative to one another (Heyl and others, 1955, p. 234).

- Heyl's note is, “The use of the term 'gash-veins' for the joint-controlled lead deposits was suggested by. Whitney (Eall and Whitney, 1862, p. 227). He stated : These deposits approach most nearly in character to what have been designated above as gashvelns * " " "

A slightly revised version of this lllustration is published in Heyl and others, 1955, p. 234. The revised version is figure 26 of this report. 


\section{SURFICIAI GEOLOGY}

A surficial layer of windblown silt or loess blankets the upland parts of the mining area, and widespread alluvium is present in many of the stream valleys. The loess is commonly 2 to 8 feet thick, but in some areas it reaches a thickness of 15 feet or more. The detailed index map (fig. 27) shows the distribution and approximate thickness of the loess in the area in which these studies were made. In general, the loess deposits are thickest along the Mississippi and become thinner to the east. Locally the thickest deposits are on the hilltops and gently sloping uplands, and the loess thins gradually in the direction of the stream valleys. On the slopes of steep-sided valleys the loess may be almost completely removed, even in areas of generally thick loessial cover.

Chamberlin (1897, p. 799-801) suggested that the sources of the loess were the valleys of the Mississippi River and other glacier-fed rivers during the Pleistocene. He postulated that as the river was flooded by melt waters from the glacier it spread silt over the flood plain. Then, as the river flow diminished, some of the silt dried and was carried to the southeast by the wind. G. D. Smith (1942, p. 152-162), who made a detailed study of the particle sizes and thickness of loess in Illinois, also concluded that the flood plains of rivers draining the glacier were the sources of the loess, inasmuch as both particle size and thickness increase as one approaches either the Illinois or Mississippi River. He found that the greatest thickness of loess was related to sections of the rivers over which the wind had a fairly long sweep across the river lowlands. His studies suggest that southwest as well as northwest winds took part in the distribution of the loess.

As part of the present study, some data were gathered concerning the mineralogy and thickness of the loess, and the amount of mixing of the loessial material with the underlying residuum. In the Potosi area, where most of the samples for the loess-residuum studies were collected, the vertical profile of surficial material could be divided into five layers or zones on the basis of color, mineral composition, grain size, and reaction to concentrated hydrochloric acid. The samples were examined under a binocular microscope with a magnification of about 30. From the surface down, the zones are as follows:

Zone A.-Partially weathered loess: a light-tan, well-sorted silt con. sisting primarily of quartz grains with a little mica and a few dark minerals; no effervescence in concentrated hydrochloric acid.

Zone B.-Partially weathered loess : a very light-tan to almost white, well-sorted silt consisting mostly of quartz but with some dark minerals and a few mica flakes; in concentrated hydrochloric acid this material effervesces slowly at first but more rapidly after about 15 seconds' contact, with practically no discrete effervescing particles visible. 


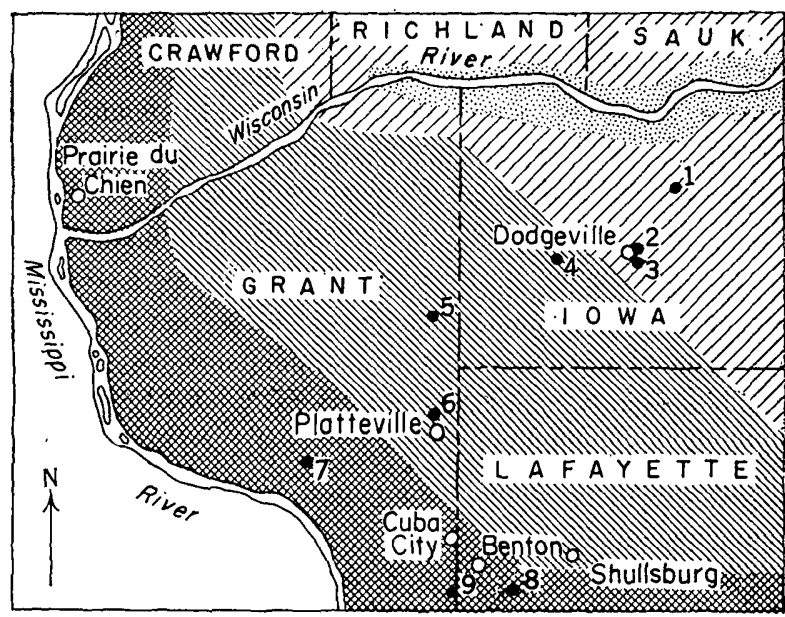

EXPLANATION

\section{$\bullet 4$}

Location of areas studied

1 Demby-Weist lead range $(\mathrm{pl}, 16)$

2 North Dodgeville area

3 South Dodgeville area (fig. 28)

4 Linden area

5 Crow Branch (pls. 8-11)

6 Trego mine

7 Potosi (pls: $12-15)$

8 Champion property (fig. 29)

9 Crawford property (fig. 29)

\section{DEPTH OF AEOLIAN SILT}

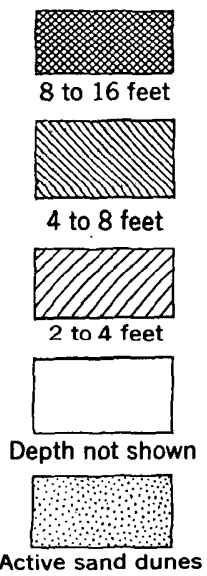

Frgtre 27. - Detalled index map showing the location of areas studied and the depth of aeolian silt (loess). Depth after Hole, 1950.

Zone C.-Partially weathered loess : very similar to Zone A.

Zone D.-Residual clay: dark-red to brown mixture of clay aggregates, quartz particles, chert fragments, and a few dark minerals; distinguished from higher zones by color, presence of clay aggre- 
gates, larger size of some of the quartz particles, absence of mica flakes, and lack of effervescence in acid.

Zone E.-Partially weathered bedrock: almost white fragments of dolomite and limestone distinctly larger than the particle size of the loess; strongly effervescent in concentrated hydrochloric acid, with effervescing particles easily visible.

All these zones were identified at some sample localities, although in many places one or more of the zones are missing. In general, the deeper the surficial material the more zones will be present.

The boundary between adjacent zones is marked by a gradual decrease in the proportion of material from one zone and an increase in the proportion of material from the adjacent zone rather than by. an abrupt contact. The gradational character of these boundaries is important in evaluating the results of chemical analysis of soil samples because the dilution of residual material (zones $\mathrm{D}$ and $\mathrm{E}$ ) with loess (zones $\mathrm{A}, \mathrm{B}$, or $\mathrm{C}$ ), if not detected, can cause an incorrect interpretation of the amount of lead or zinc in residuum near known mineralized areas.

The following procedure was used for estimating the relative amounts of loess and residuum in any soil sample: The sample was dried and crushed to pass an 80-mesh sieve. A part of this material was spread on white paper under a microscope and a drop of concentrated hydrochloric acid placed upon it. The reaction to acid serves to indicate the amount and type of calcareous material present and also to make it easier to see the individual grains. The presence or absence of iron-stained clay aggregates, chert particles, mica flakes, and various types of calcareous material was noted and an estimate made of the percent of residuum present in the sample. This technique is useful principally for samples consisting of a mixture of loess and residuum. Material that is mostly either pure residuum or pure loess can be easily identified by simple megascopic observation of color and apparent clay content.

\section{METHODS OF SAMPLING}

\section{WATER}

The following methods were used in collecting water samples:

1. Spring and stream water: $50 \mathrm{ml}$ of water were collected in a 100-ml glass-stoppered graduated cylinder.

2. Farm wells: The well was pumped continuously for at least 10 minutes either by hand or mechanically to remove as much contaminated water as feasible. A 50-ml sample was then collected directly from the pump in a 100-ml glass-stoppered graduated cylinder.

3. Drill holes: The water sample was collected in a steel bottle of the type shown in figure 30 . The bottle was lowered to the required 
depth in a drill hole, opened and filled, and then withdrawn from the drill hole and the water emptied into a 100-ml graduated glassstoppered cylinder.

SOI

The soil samples were collected with a standard soil auger, consisting of one or more 3 -foot lengths of $3 / 8$-inch pipe fitted with a $11 / 4^{-}$ inch wood bit at the bottom, and a T-handle at the top. Ten to twentyfive grams of soil were collected from the required depth and placed. in a paper envelope. These samples when dry, were pulverized in a porcelain mortar and passed through an 80-mesh sieve before analysis.

Sample points were laid out by tape and compass traverses and tied in to prominent land marks. Because most of the samples were collected in cultivated areas, it was not feasible to leave permanent markers at most of the sample sites.

\section{ROCK}

Samples were taken from churn-drill cuttings (by bagging a grab sample) as each cut was removed from the drill hole. Customarily in this mining district a sample of rock cuttings is removed at 5-foot intervals, but where unusual quantities of zinc and lead or a bed of particular interest is found, the cuttings may be taken at 1- to 2.5foot intervals.

\section{METHODS OF ANALYSIS}

\section{WATER}

Huff's method (1948) of analysis for heavy metals in water was used. In brief, the method consists of shaking a known volume of water, which has been buffered to a $\mathrm{pH}$ of about 5.5 , with $5 \mathrm{ml}$ of a 0.0016 percent weight per volume solution of dithizone in carbon tetrachloride. Copper, lead, and zinc are the most common elements reacting with dithizone under the conditions of the test. As little as 0.1 microgram of zinc and 0.5 microgram of lead or copper in 50 $\mathrm{ml}$ of water may be detected by this method of analysis. The dithizone solution changes from the green of the pure state to a blue, purple, or red, depending upon how much heavy metal is present. Because the heavy metals all have a similar reaction with dithizone, the resultant color is the sum of the effects of all the heavy metals. The, measured amount of heavy metals is expressed in terms of parts per million (ppm), and a sample of water which produces the same color in the dithizone solution as a sample of water containing $1 \mathrm{ppm}$ zinc is said to be $1 \mathrm{ppm}$ in total heavy metals. Zinc may be determined specifically by adding sodium thiosulfate solution to the water before shaking. 


\section{$\therefore$ SOIL}

Lakin, Stevens, and Almond's method (1949) for zinc was used in all of the analyses made in the field. This test requires a potassium bisulfate fusion followed by an estimation of the zinc content by use of dithizone. In the laboratory several other methods of soil digestion were tried on selected samples under the supervision of Harold Bloom, and a digestion of a $0.1 \mathrm{~g}$ of soil for 1 hour in $2 \mathrm{ml}$ of approximately $4 \mathrm{~N}$ nitric acid was found to be satisfactory for zinc determinations; in addition, the nitric acid extracted lead more consistently than did the bisulfate fusion. Before the amount of lead or zinc were estimated in the nitric acid solution, the solution was diluted to $10 \mathrm{ml}$. Not more than $3 \mathrm{ml}$ of the diluted solution were added to $8 \mathrm{ml}$ of a buffer of the type used in the bisulfate fusion method for zinc; the estimation of the amount of zinc present was made by shaking the buffered solution with a dithizone solution and comparing the resultant colors with a series of standards similarly prepared. The lead estimate was made by the method described by Almond and Morris (1951, p. 613).

In addition to the two field methods of analysis just described, a third method was tested on the samples from just one area. This method differed from the nitric acid method just described in that $4 \mathrm{ml}$ of $2 \mathrm{~N}$ nitric acid were used as the digesting liquid instead of $2 \mathrm{ml}$ of $4 \mathrm{~N}$ nitric acid. The samples digested by the third method were analyzed for total heavy metals essentially in the manner described by Huff (1951, p. 530) and for lead in the manner described by Almond and Morris (1951, p. 613).

Quantitative methods for lead, zinc, and copper modified from Holmes (1945, p. 77-84) were used as the standards against which the various field methods were compared. These quantitative values are believed to be, in most instances, within 10 percent of the actual amount of lead or zinc present in the sample.

In evaluating the usefulness of the various methods of field analyses it must be realized that completeness of extraction is not the same for the different methods of extraction which were used. In comparison with the quantitative method, the zinc values obtained by the bisulfate fusion field method tend to be high, the $4 \mathrm{~N}$ nitric acid digestion gives results comparable to laboratory values, and the $2 \mathrm{~N}$ nitric acid method gives results that are low. For lead, the bisulfate fusion method gives low results, the $4 \mathrm{~N}$ nitric method slightly low results, and the $2 \mathrm{~N}$ nitric acid method erratically high and low results. Therefore, all of the samples from any one area should be analyzed by the same method in order to obtain comparable data. In areas where much lead and zinc are present, any of the methods of analysis described will serve to detect them; however, the $4 \mathrm{~N}$ nitric digestion 
seems to give values for both lead and zinc that are close to the values found using the quantitative methods.

\section{ROCK}

The rock samples were analyzed for lead and zinc by the $4 \mathrm{~N}$ nitric acid method used for soils and were analyzed for.iron by the o-phenanthroline method (Sandell, 1944, p. 271-273).

\section{LEAD, ZINC, AND IRON IN ROCK AND SOIL OVER ZINC DEPOSITS}

In southwestern Wisconsin most of the lead deposits occur as vertical or nearly vertical veins, whereas the zinc ore bodies commonly have their longest dimensions in a nearly horizontal plane. The majority of the zinc ore bodies therefore, crop out only in the north-. ernmost part of the mining district where the gently dipping host rocks are cut by the present erosion surface. Elsewhere, exploration for zinc deposits must be guided either by geologic structures or by some chemical or mineralogical feature of the overlying rock, such as a primary halo.

In order to determine whether primary halos occur in the strata overlying the zinc deposits, studies were made of the amount of lead, zinc, and iron in drill cuttings collected from strata above known ore bodies in the Shullsburg and Crow Branch areas (see fig. 27). Samples of soil overlying the Crow Branch deposits, as well as other small, flat-lying zinc deposits, were also studied in an effort to detect secondary anomalies.

\section{SHULLSBURG AREA}

The Calumet and Hecla Mining Company made available their drill logs from the vicinity of two ore bodies and from areas believed to be barren of ore-grade mineralization. Estimates by the company geologists of the amount of zinc present as visible sphalerite, of lead occurring as galena, and of iron occurring as pyrite or marcasite were recorded from 5 -foot cuts in the greater part of most drill holes, and for smaller cuts where the lead and zinc content was high. The lower limit of macroscopic estimation of zinc as sphalerite and lead as galena. was approximately 0.1 percent, and of iron as pyrite or marcasite was approximately 0.25 percent. These data have been compiled in plate 7 .

A greater amount of pyrite, marcasite, and galena occurs in the rocks overlying ore bodies than in equivalent rock units in "barren" areas. Over one deposit, the visible sphalerite is more abundant in the rock above ore than in equivalent rocks in "barren" areas, whereas over one other deposit, the reverse relationship was found. 


\section{CROW BRANCH AREA}

\section{SOIL SAMPLING}

At Crow Branch (fig. 27, no. 5) a study was made of the lead and zinc content of soil in the vicinity of an area known to be well mineralized. The exact sources of the richest ore mined are not known; however, the most productive area is marked by several caved shafts and many prospect pits. The depth to the main ore-bearing beds gradually increases as one moves southeastward across the area studied. The ore cropped out in the stream valley at the north end of the Crow Branch area (see pl. 8), and lay about 110 feet below the surface near the southernmost shaft. Information concerning geologic structure and mineralization in drill holes, as shown in plates 8 and 9, was obtained from U. S. Geological Survey Circular 131.

Loess is present over most of the area studied at Crow Branch. In general the loess is thickest in the southeastern part where it reaches a maximum depth of about 6 feet. In the northern and southwestern parts erosion along the streams has stripped away both loess and residual soil, and bedrock is exposed.

In sampling soil from this area an attempt was made to get residual material, but in some samples a mixture of loess and residuum was collected-as shown by later microscopic examination. When placing the analytical data on plate 9 , the approximate amount of loess present in a sample was indicated by the method of plotting. Samples estimated to contain less than 20 percent residuum are not shown and samples estimated to contain from 20 to 50 percent residuum are plotted with a special symbol.

Despite the problem of sample dilution by loess, four geochemical soil anomalies were outlined by the data of plate 9 . Anomaly $A$ corresponds closely to the location of the old shafts and prospect pits, and anomaly $B$ is related to a lead vein. The reason for the presence of anomaly $C$ is not known, but it may represent a number of undiscovered lead veins, a second zinc sulfide deposit, or the effect of primary leakage of ore-bearing solutions moving upward along bedding planes from the site of deposition of the main ore body. Anomaly $D$ is also unexplained but may be the result of mineralization of the eastern limb of the Crow Branch syncline.

One of the reasons for choosing the Crow Branch area for detailed study was the fact that the depth from the surface to the ore-bearing level ranges from essentially nothing near the creek at the north end of the ore body to about 110 feet at the southernmost shaft. Thus an opportunity was afforded for determining whether the size of the lead-zinc anomaly is related to the depth of the ore. The results obtained by soil sampling, as shown in plate 9 ; indicate no direct relation between the intensity of the geochemical anomaly and the depth 
to ore. The lack of much lead and zinc on the northernmost traverse, where the samples represent partially weathered bedrock taken only a few feet above the ore, is difficult to explain. Observations elsewhere show that anomalies in weathered rock are not so marked as those in residual soil, and this may, in part at least, account for the absence of a strong geochemical indication of the ore at this locality.

\section{ROCK SAMPLING}

During the fall of 1949, after soil sampling had been completed at Crow Branch, both the U. S. Geological Survey and the Dodgeville Mining Company did some drilling there. The holes drilled at this time by the Survey are those numbered USGS $1 \mathrm{~A}$ through 4 and 6 and 7 on plate 9 ; those drilled by the Dodgeville Mining Company are numbered 1 through 6 . Drill-hole numbers used for U. S. Geological Survey holes correspond to those used by Heyl, Lyons, and Agnew (1951, p. 7). Drill cuttings were collected from USGS 7 and from Dodgeville Mining Company holes 5 and 6 (see pl. 9). The cuttings were analyzed for zinc, lead, and iron and the results are presented in plate 10. The cuttings removed from Dodgeville Mining Company hole 6 contained low concentrations of zinc, lead, and iron in contrast to the cuttings from the other two holes. The explanation for this contrast is believed to be the presence of sphalerite, galena, pyrite, marcasite, and their oxidation products in the rock near the main Crow Branch mineralized zone in concentrations large by comparison with that at a distance from ore.

During the summer of 1952 the Dodgeville Mining Company drilled seven additional holes in a line cutting across the projected southeastern extension of the Crow Branch ore zone (see pl. 9). Samples of the drill cuttings were collected from each of the drill holes and analyses were made for zinc, lead, and iron. The analytical results are presented graphically in plate 11 . The data suggest that a lowgrade extension of the Crow Branch zone crosses the line of drill holes near Dodgeville Mining Company hole 9.

A comparison of the lead and zinc concentrations in the soil near Dodgeville Mining Company holes $7-13$ with the concentrations of these elements in rock from these drill holes indicates that the anomalies in the rock correlate with the anomalies in the soil (pl. 9). Thus the primary nalo associated with the Crow Branch ore body apparently can be detected by analyzing residual soin.

The lead and zinc content of the rock in which the primary halo is present is, for the most part, less than 0.1 percent. This fact is important when evaluating the data on mineralization over ore in the Shullsburg area (pl. 7). At Shullsburg the lowest concentration of lead and zinc of which an estimate was made was about 0.1 percent. Thus the primary halos in the Shullsburg area may extend farther 
above the ore than was indicated by visual methods of estimating lead and zinc, for any primary mineralization over ore in the concentration range background to 0.1 percent would be missed by visual estimation.

Comparison of the intensity and size of the primary halos of zinc, lead, and iron in Dodgeville holes 7-13. (pl. 10) shows that lead produces the smallest and least intense halo, zinc is intermediate in this respect, and iron produces the most widespread pattern. 'In this particular area the intensity of mineralization in the rock over the orebearing layers appears to be related to the amount of ore present (compare Dodgeville holes 5 and 9 and USGS 7 with Dodgeville hole 6 , in pl. 10).

\section{NORTH DODGEVILLE AREA}

Soil samples were collected from 8 points on a 200 -foot traverse crossing above a mined-out ore body at the northeast corner of Dodgeville. The traverse runs northward from Spring Street at a point approximately 1,000 feet east of the Dodgeville Mining Company shaft. The top of the ore was about 50 to 60 feet below the present land surface. Later microscopic examination showed that 2 of the soil samples collected had a high proportion of loess; so there were only 6 samples of residuum available for analysis. The lead content of these samples ranged from 70 to $1,700 \mathrm{ppm}$ and averaged $650 \mathrm{ppm}$; the zinc content ranged from 200 to $1,100 \mathrm{ppm}$ and averaged $590 \mathrm{ppm}$. The metal content of these soils is definitely higher than the normal background level of 15 to $30 \mathrm{ppm}$ lead and 50 to $100 \mathrm{ppm}$ zinc and strongly suggests the presence of a primary anomaly in the rocks overlying the ore.

\section{SOUTH DODGEVILLE AREA}

Figure 28 shows in plan the location of known ore and the sample points where material consisting mostly of residuum was collected. Some samples found to consist primarily of loess or alluvium are not reported, and this accounts for the gaps in the data along some of the traverses. The crest of a low hill runs almost east-west through point $E$ and the land slope is about $6^{\circ}$ in a direction slightly east of south on the south side of the crest and about $10^{\circ}$ to the north on the north side of the crest. The top of the ore lay at a depth of 70 to 80 feet on traverse $G H, 110$ to 120 feet on traverse $E F$, and about 100 feet on traverse $A B$. A correlation of metal-rich soils with underlying ore is marked in the $G H$ traverse but is not apparent on traverses $A B, B C$, or $E F$.

Traverse $I J$ was made to see whether an extension of the ore zone could be located. Although the anomalies found near the east end of the traverse suggest a possible ore extension, drilling by the Dodgeville Mining Company after the soil sampling was completed did 


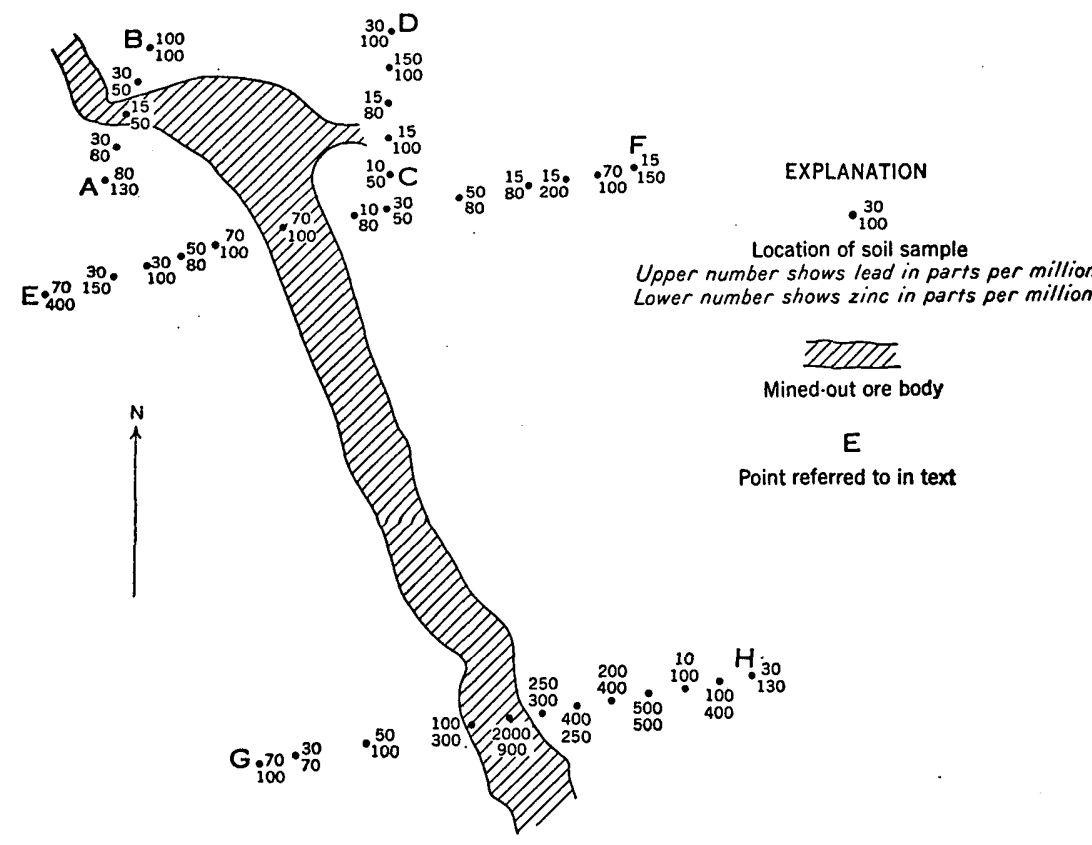

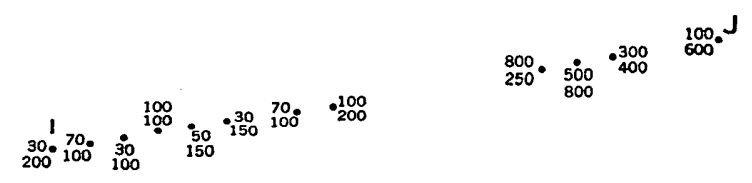

Frgone 28.-Lead and zinc content of soil near an ore body southeast of Dodgeville, Wis.

not show the presence of strong lead or zinc mineralization although much iron was found.

\section{IINDEN AREA}

Six soil samples were collected over the Prairie mine about 1.2 miles north of Linden (fig. 27, no. 4) to determine whether unusual amounts of lead and zinc are in the soil overlying an area where ore had been mined at a depth of about 75 feet. The results, though not conclusive, indicate a slight lead anomaly above the ore, but no detectable zinc anomaly.

\section{TREGO MINE}

A study at the Trego mine, about 2 miles north of Platteville (fig. 27, no. 6) showed normal amounts of lead and zinc in the soil overlying the ore; this indicates that if any primary halo is present above the ore it does not extend to the surface of bedrocir.

The ore lay about 140 to 150 feet below the surface and the three short soil-sampling traverses crossed directly above the location of the ore body. Heyl (oral communication) states that the rock over the 
ore body did not seem to be highly fractured, and this suggests that open channel ways for the ore-bearing solutions did not extend far toward the surface.

\section{LEAD AND ZINC IN SOIL OVER LEAD VEINS}

In addition to a study of primary halos over zinc ore bodies and the secondary patterns derived from them, a study was made of the lead and zinc anomalies formed in soil during the weathering and erosion of gash-vein lead deposits. Because of the manner in which they are deposited, the gash-vein ore bodies are the ones most often found forming an outcrop, and it is this type of deposit which was studied to obtain information on secondary patterns formed near outcropping ore.

\section{POTOSI AREA}

In the Potosi area (fig. 27, no. 7), as in much of the southwestern Wisconsin zinc-lead area, a layer of loess covers almost all of the residual soil. The loess near Potosi reaches a thickness of at least 15 feet on flat hilltops, but may thin to only a few inches on steep slopes. The loess has completely buried and preserved residual soil over areas many thousands of acres in extent. The result is that geochemical anomalies, if present in residual soil near lead veins, can be studied by augering through the loess and collecting residual soil samples. Because the loess is thick, this area offered an excellent opportunity to determine how far upward into the loess abnormal quantities of lead and zinc could be found where the underlying residual clay contains unusually large concentrations of lead and zinc.

A map of the general area studied near Potosi is presented in plate 11. The locations of the many gash-veins which have been mined or only prospected are shown, and points where detailed studies were made are marked.

\section{POINT J}

Near point $J$ a series of soil samples was collected across a lead vein which apparently contained only small quantities of lead near the surface. Results of analysis of these samples are presented in pl. 13. In this area the land slope was so great that there was little residual clay present when the loess was deposited; also, much of the loess has been eroded since it was originally deposited. The soil then, consists of a layer of loess overlying partly weathered bedrock into which is mixed a small amount of residual clay. No galena was seen in any of the material thrown out of the prospect pits, and none of the soil samples contained high concentrations of lead or zinc. An examination of the data in plate 13 shows that, although the mineralization is slight, an unusual concentration of both lead and zinc is present in the soil near the prospect pits. The data indicate that there is also a 
second, slightly mineralized, zone located in the vicinity of the sample taken 160 feet downslope along the traverse (see pl. 13), but there are no prospect pits on this zone. The secondary anomaly associated with this mineralized area is comparatively small, and sample spacing needed to detect such anomalies would be of the order of 20 feet.

\section{POINT $\mathbf{L}$}

The traverse south of point $L$ is more nearly typical of the conditions near the tops of the hills than was the traverse near $J$. The depth of loess ranges from 7 to 9 feet and the thickness of residual clay and partially weathered bedrock combined ranges from 1 to 5 feet. Plate 14 shows the results of the analysis of soil samples collected on this traverse. Anomalies found by soil analyses correspond well with the location of areas thoroughly prospected and, in some instances, mined by the early miners. Samples were not taken on the traverse between 100 and 170 feet because the iron-stained rock and soil on the surface indicated that the area had been dug over so much that an undisturbed soil profile could not be found. The fact that the residual soil samples downslope from this area contain more lead than the soil samples taken upslope from the disturbed area suggests that a source of lead is present in the area between 100 and 170 feet along the traverse. The samples collected at the sample point 60 feet along the traverse are obviously in disturbed ground, because unusual quantities of lead and zinc are present throughout the soil profile and microscopic examination showed the presence of residual soil in several of the samples. The high concentration of lead in the surface soil at this point can be correlated with the occurrence of pieces of galena in the disturbed soil.

Plate 14 indicates that several of the surface samples contain relatively large amounts of lead and zinc. Every surface sample which is high in lead and zinc content is in an area where bedrock and residuum were thrown to the surface during mining operations by prospectors and later spread over the land by farmers leveling off the dump material.

Sampling on this traverse was done at much closer intervals than would be necessary in prospecting a similar area, for sampling at 50foot intervals would have identified this area as being mineralized. Highest zinc concentrations were 5 to 8 times normal, and lead concentrations were as much as 35 times normal.

\section{POINT M}

The traverse south of point $M$ crossed the crest of a hill on which the thickness of loess was as much as 11 feet. Plate 15 shows a plan view of the sample points and of the lead veins which have been thoroughly prospected in times past, as indicated by a line of disturbed soil striking into the sampling area. In addition to the disturbed surface soil 
associated with known veins there is a disturbed soil area at 150 feet along the traverse. No line of old prospect pits trends into this area; so, it is assumed that this is an isolated prospect pit.

The vein intersecting the traverse at 210 feet is the only one in this particular area shown on the geologic structure map of the Potosi area (Heyl, Lyons, and Agnew, 1948); so presumably it is the most important vein in terms of lead production. Unusual quantities of lead and zinc are present in the soil in a zone 90 feet wide near this lead vein, but most of this zone is on the upslope side of the vein. Hence, there is reason to believe that an additional source of lead and zinc occurs upslope from the main lead vein. Possibly the disturbed soil at 150 feet marks the southern boundary of this anomalous area.

Lead is present in quantities slightly above normal in the soil near the sample points at 20 and 80 feet along the traverse. The anomaly at 20 feet is almost in line with some old prospect pits or shallow mines, but the anomaly at 80 feet has not been investigated by digging.

The concentrations of lead and heavy metals determined for the samples on this traverse were appreciably lower than those on other traverses because a mildly digested sample was used $(2 \mathrm{~N}$ nitric acid digestion); nevertheless, areas containing much lead and zinc were detected. Zinc concentrations were obtained by using the bisulfate fusion method--a method which entails much more thorough extraction than that used for the lead and heavy-metals tests.

\section{CHAMPION AND CRAWFORD PROPERTIES}

At both the Champion and Crawford properties (fig. 27, nos. 8, 9), the loess is generally thick and overlies what is known as a "lead range," or series of subparallel lead veins. The residual soil above these lead deposits contains unusually large concentrations of lead and zinc that are due to weathering of ore-bearing rock. Because of the mixing action during the formation of soil from rock, the area of soil in which much lead and zinc are found is larger than the area occupied by the lead veins themselves. Therefore the residual soil between lead veins contains unusual concentrations of lead and zinc. In such areas it is possible to determine the distance to which lead and zinc will move upward into the loess and also to get some idea of the method of movement, whether by mechanical mixing or by solution and redeposition. This is done by examing the loess microscopically for traces of the iron-stained residuum and by analyzing the loess chemically for traces of lead and zinc.

At the Champion property the Bureau of Mines had cut a deep trench across the lead range to bedrock. From this trench at one point near a known lead vein a series of soil samples was collected at 1-foot intervals in depth from the surface to bedrock. The lead 
CHAMPION PROPERTY
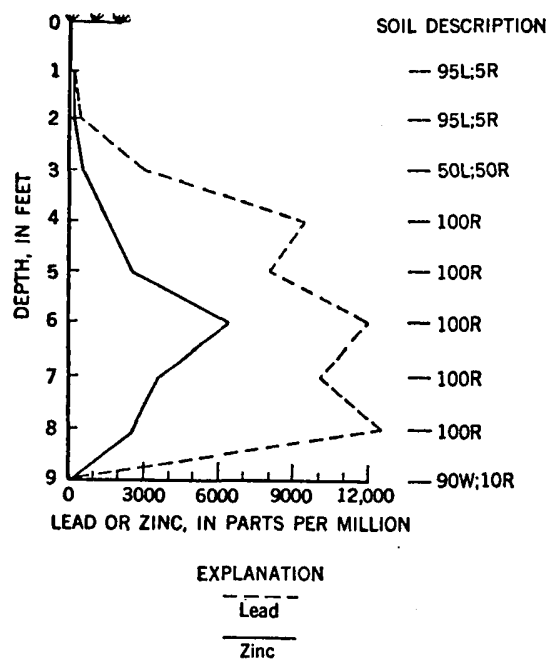

Soil constituents in percent (estimated)

L, Loess

$R$, Residual clay

W, Partially weathered bedrock
CRAWFORD PROPERTY

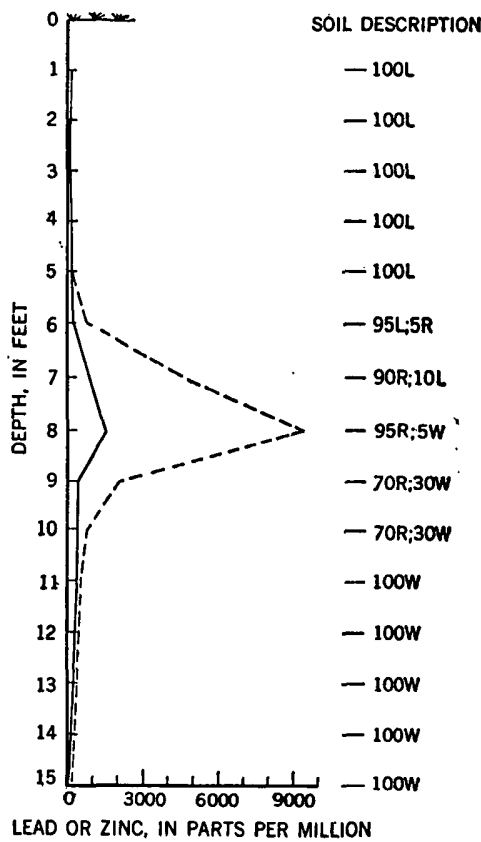

FrGURE 29.-Relation of soll constituents to lead-zinc content at the Champion and Crawford properties.

and zinc content of these samples are compared in figure 29 with the residuum content of the sample estimated by use of a microscope.

Similarly, soil samples were collected from the side of a test pit dug by the Bureau of Mines on the Crawford property. These samples were examined to determine the relative amounts of loess and residuum and the information was compared with chemical analyses (fig. 29).

Although the loess and residuum proportions shown in figure 29 are only estimates, a correlation seems to exist between the estimated residuum content and the lead-zinc concentration of the samples from both the Champion and Crawford properties. Therefore, it is probable that most of the lead and zinc in the lower 2 to 3 feet of loess is present because of mechanical mixing rather than because of upward movement of solutions carrying lead and zinc.

\section{DEMBY-WEIST LEAD RANGE}

The Demby-Weist lead range lies about 7 miles northeast of Dodge. ville in the $W^{1 / 2} \mathrm{NW}^{1} / 4$ sec. 28 , T. 7 N., R. 4 E. (fig. 27 , no. 1). The range consists of at least two veins from which galena has been mined. Plate 16 shows the location of the sample traverse in respect to the westernmost vein and presents the results of analyses of soil samples for lead and zinc. 
An effort was made to auger to bedrock at each sample point, but at the eastern end of the traverse chert was struck in augering and bedrock was not always reached. Nevertheless, the essential fact is obvious that the soil near the known lead vein has a very high lead content. An examination of plate 16 clearly shows that there are high concentrations of lead and zinc in the soil to the west of the vein being examined. The anomaly at 370 feet from the beginning of the traverse is about 30 feet west of the known lead vein and, unless the present caved mine shafts are not directly on the known vein, probably indicates a new vein. The direction of soil movement is such that soil from the known lead vein would not produce the anomaly at 370 feet. Pieces of galena were found in the residual clay at this point at a depth of about 5 feet; thus the presence of unusually large concentrations of lead and zinc is shown both by unaltered ore minerals and by unusually large amounts of lead and zinc in the soil, as indicated by field tests. High values for both lead and zinc are present also at a point 300 feet along the traverse and may be indicative of another mineralized zone.

When the soil samples were first collected, only the bisulfate fusion test for zinc was used and the values shown in the upper half of plate 16 were obtained. When later experiments in other parts of this mining area indicated that lead tests were desirable, a series of samples taken along the traverse at depths of 1 foot, regardless of soil composition, was analyzed for lead as well as for zinc to see what sampling at some arbitrary shallow depth might show; also, a series of samples believed to be entirely residual material was analyzed. It is apparent from a comparison of the analytical results of samples from a 1-foot depth and samples of almost pure residuum that some anomalies detected by sampling residuum would have been missed by sampling done at a 1-foot depth. It is also apparent, especially frcm the analyses of residuum, that at the Demby-Weist lead range high concentrations of zinc are not necessarily accompanied by similarly high concentrations of lead, although all high lead concentrations seem to be accompanied by high zinc concentrations. The data on residuum clearly show that unusual amounts of zinc are distributed throughout the area studied and that sampling, even at 200- to 300 foot intervals, would have shown this to be a mineralized area. With the exception of one or two samples, the lead contents also were at least three times the normal concentration of 15 to $30 \mathrm{ppm}$ in residuum.

\section{LEAD AND ZINC IN GROUND AND SURFACE WATER}

In order to obtain some idea of the extent to which the heavy metals from the ore deposits in this mining area go into solution in ground water, waters from three different sources were obtained and analyzed. 
Samples of water from drill holes cutting ore, from holes close to ore, and from holes in so-called barren rock were collected and analyzed. Spring waters in the vicinity of Potosi were analyzed to determine what concentration of heavy metals in solution could be expected near, and at some distance from, areas known to be mineralized. Stream waters were analyzed to see how well they reflected the heavymetal content of the springs and seepages constituting their source.

\section{WATER FROM DRILI HOLES}

water samples were collected and analyzed from drill holes bored primarily for prospecting purposes and also from drill holes being used as farm wells. The study of water from drill holes was made almost entirely in the vicinity of Shullsburg because the Calumet and Hecla Consolidated Copper Company and the Vinegar Hill Zinc Company were conducting drilling programs there and water samples from their drill holes were readily available. A little experimentation indicated that the heavy-metal content (almost all zinc) of the water varied somewhat with depth in the drill holes. In order to permit sampling at any particular depth a special water sampler was designed for use in drill holes. A glass sampler with a cork stopper was built first, on the general principles shown in figure 30 . This model burst when opened at a depth of 300 feet below the water table. Later a steel model was built which was coated on the inside with hot paraffin to prevent contamination. This sampler was found satisfactory for collecting water from any desired depth. The results of sampling water from drill holes located at various distances from ore are shown in plate 17. Ore is defined here as rock containing an average of 3 percent of zinc through a depth range of 5 feet. The first five holes logged were not known to be near ore but, as in many holes drilled in this mining area, traces of sphalerite were seen in some of the drill cuttings. The range of heavy-metal concentrations in water from these holes was from 0.02 to 0.08 and averaged $0.035 \mathrm{ppm}$. Holes 6 to 10 were those containing little or no recorded sphalerite but were known to be within 200 feet of drill holes penetrating ore. The average heavy-metal concentration from these holes was $0.10 \mathrm{ppm}$ and the rango was 0.06 to $0.16 \mathrm{ppm}$. Drill holes 11-22 are known to penetrate rock containing at least 3 percent or zixo through a depth range of 5 feet or more. The average heavy-metal content of the water in these holes was $0.08 \mathrm{ppm}$ and the range was from 0.02 to $0.5 \mathrm{ppm}$.

As there is no way of knowing whether ore occurs near some of the drill holes penetrating barren or only slightly mineralized rock, tho concentrations above 0.02 or $0.03 \mathrm{ppm}$ in holes 1-5 may indicate zinc mineralization nearby. The water from drill holes near but not penetrating ore shows abnormal concentrations of heavy metals in every 


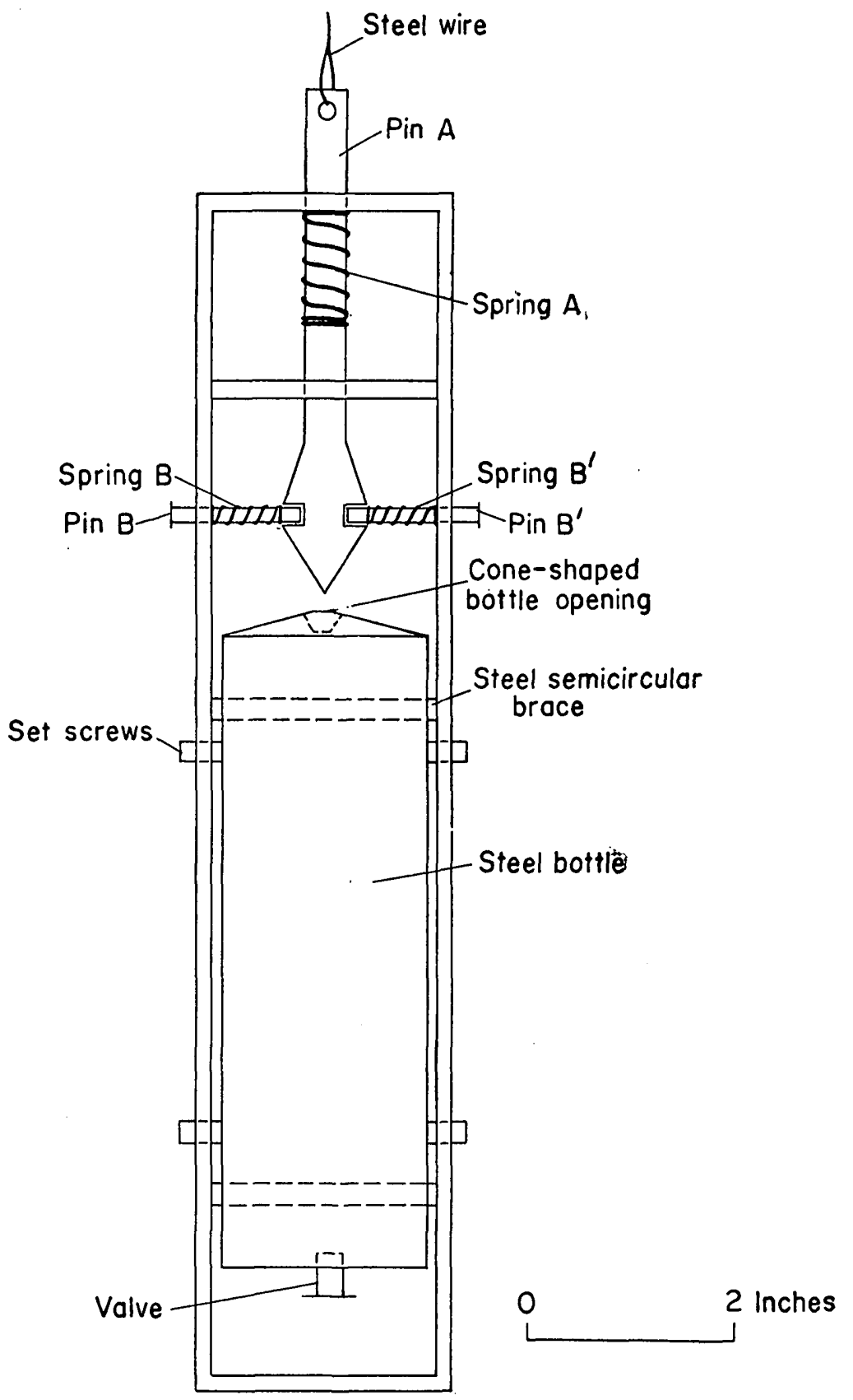

Figdre 30.-Steel water-sampler used in drill holes.

hole even though the known ore is located slightly downslope from some of the holes (as nos. 6-8). A possible cause of the anomalies in holes 6-8 is the proximity of the ore minerals to the water table; such proximity would be expected to result in an increased rate of oxidation 
and solution of both the ore body and the scattered ore minerals found in the vicinity of the ore. Holes 9-10 are downslope from ore, but the ore is at a greater depth below the water table than it is in drill holes $6-8$, and active solution of the ore minerals is probably not rapid. Most of the drill holes penetrating ore do not contain unusually large quantities of heavy metals in the water everywhere throughout the hole. This suggests relatively little vertical mixing in the drill holes. Some of the water samples collected within a few inches of zinc-lead ore showed only a small increase in heavy-metal content over that found in slightly mineralized holes. The reasons for this are not known, but lack of oxidizing conditions may be the cause.

Two additional factors which have a bearing on the heavy-metal content of the water are the amount of turbidity and the difference of water pressure in the various beds. Some of the highest concentrations of heavy metals were found in water samples which were very turbid. It is possible that the buffer used in the water test caused the solution of small amounts of zinc from the minute particles of sphalerite undoubtedly present in suspension in some holes. ${ }^{5}$ Unfortunately, the importance of turbidity as a factor influencing the heavy-metal analyses was not realized until much of the work had been done, so that the lack of a notation in plate 17 concerning turbidity does not indicate its absence. In fact, a perfectly clear sample was the exception rather than the rule, because lowering the sampling bottle down the drill hole usually stirred up fine particles that had settled out on the side of the hole after drilling was completed.

In some drill holes the observed differences in water pressure from bed to bed appeared to be considerable. This phenomenon is not uncommon, according to A. F. Agnew (written communication), for many drillers in the mining area have reported marked fluctuations of water level during drilling. If these pressure differences remained after drilling was completed (and there are no verified records of this) there would certainly be vertical movement of water in the drill holes, and a water sample collected at any specific depth would not necessarily represent the water present in the rock a foot or two away. This movement of water up or down a drill hole apparently did not cause thorough mixing of water throughout the hole for, as noted previously, samples from different depths in the holes contained different amounts of heavy metals.

s An attempt was made to extract zinc from finely divided sphalerite in the laboratory by using the standard test for heavy metals in water. Little or no zinc was extracted. When similar sphalerite was shaken with distilled water and let stand for 3 dass sufficient zinc was dissolved to give a strong showing of heary metals. The latter situation corresponds closely to that present in the field during the analysis of water from drill holes. 


\section{WATER FROM FARM WELLS}

A study of the heavy-metal content of farm wells was included as part of the general study of ground waters. Relatively few samples were needed from farm wells to show that the running of water through the well pipes was not adequate to rinse them clean of dissolved heavy metals derived from metal in the plumbing. Of the water taken from 10 wells, none contained less than $0.2 \mathrm{ppm}$ of heavy metals and 1 , located in an area believed to be barren on the basis of drill holes surrounding it at distances of a few hundred feet, contained 7.5 ppm of heavy metals. The lowest concentration of heavy metals found in farm wells corresponded in amount to the higher concentrations found in drill holes penetrating ore, but 7 of 10 water samples exceeded any concentrations found in drill-hole water present near good zinc ore. One of the wells, when sampled, had been pumping for 4 hours and still had $1.0 \mathrm{ppm}$ heary metals, whereas another farm well contained only 0.2 ppm after 10 minutes pumping. Apparently zinc from the piping, which is variable in amount, can obscure any natural concentration that may exist and the two cannot be distinguished. No way is known to determine the natural heavy-metal content of ground water drawn from the farm wells of this area.

\section{WATER FROM SPRINGS AND STREAMS}

A study of spring and stream waters was made in the Potosi area, with results shown in plate 12 . Here the local relief is great enough for springs to be common, although the slopes generally do not exceed $10^{\circ}$ to $15^{\circ}$. Lead veins are abundant, especially on the hilltops, and the zinc-bearing beds are near enough to the water table for the zinc deposits to be oxidizing.

Plate 12 shows the results of spring, stream, and mine drainage analyses, as well as the location of lead veins and abandoned zinc mines.

Heavy-metal content was determined by the test devised by Huff (1948, p. 675-684), and the $\mathrm{pH}$ determined by indicator solutions and a Hellige comparator. The lowest concentrations of heavy metals found in spring water were of the order of $0.01 \mathrm{ppm}$, whereas those found in streams were less than $0.002 \mathrm{ppm}$. These concentrations can be used as the normal quantities on which to base a comparison of heavy-metal concentration in other samples taken in the same area. The heavy-metal content of some springs and streams was appreciably greater than normal, and a reasonable explanation for these anomalies is the presence of relatively large concentrations of heavy metals in the mass of rock from which the water was draining.

An examination of plate 12 shows that most springs containing abnormal concentrations of heavy metals are near known lead veins. 
The spring at point $A$ (northeastern corner of map, pl. 12) contains about $0.45 \mathrm{ppm}$ heary metals and drains an area containing lead veins. To the south of this spring are other springs whose waters are uncommonly high in heavy-metal content, but no prospect pits were found upon a cursory examination upslope; thus there may be an undisturbed lead vein or zinc deposit nearby. At point $B$ the water entering the stream from the north side contains more heavy metals than that coming from the south side. A possible explanation is the presence of a lead vein or an undiscovered zinc deposit just north of the stream.

The spring water near point $C$ contained a greater amount of heavy metals than was found in the water from any other spring in the area not known to be draining a mined area. Soil samples taken near the lead veins lying upslope from this spring showed only normal quantities of zinc, and because zinc is the major heavy metal in the spring water, the lead veins, at least those exposed at the surface, do not seem to be the logical sources for the zinc, although there may be zinc present in them at depth. Allen V. Heyl (oral communication) pointed out that sphalerite is abundant in the Decorah formation at the adit located about 1,200 feet southeast of point $C$ and that the sphalerite is present in a "replacement deposit of the 'pitch-and-flat' type." He suggested that a similar deposit may account for the zinc in the spring water at point $C$.

The owner of the spring near point $C$ stated that small quantities of sphalerite had been taken from a shallow shaft a few hundred feet southwest of the spring. Unfortunately, this shaft could not be found.

Since the work described above was completed, drilling followed by development work has disclosed the presence of a rich zinc ore body lying under the hill to the south of point $C$ (anonymous, 1955). The topography is such that drainage from part of the ore body would be toward the spring at point $C$.

Very probably the mine drainage at point $D$ and the spring to the southwest of $D$ contain unusually large amounts of heavy metals derived from the small quantities of lead and zinc minerals remaining after the mining operations.

The high concentration of heavy metals at point $E$ is due to sewage from a cheese factory situated upstream from that point. The use of galvanized equipment may account for the zinc in the sewage. The stream to the west of point $F$ undoubtedly contains waters draining from an area of lead veins lying to the north and northeast. The slight anomaly in the spring waters near point $G$ cannot be explained by any lead veins that have been mined; however, there are a few old prospect pits upslope to the south of the spring and analyses 
of soil to the west of point $G$ indicate that a mineralized zone strikes into the area lying upslope from the spring.

Because analysis of the stream near point $H$ suggested that there was a source of heavy metals in the vicinity, five soil samples were collected along the east side of the stream and analyzed to see whether the lead vein striking into the area from the southeast continued through the suggested source area. Two of the soil samples contained 10 times the normal amount of zinc and 5 to 10 times the normal amount of lead. The results of the soil analyses and the presence of a lead vein to the northwest of point $B$ in line with a vein to the southeast indicate that the vein is continuous and is not broken into two separate segments.

At point $I$, the anomalous quantities of heary metals in spring water may be derived in part from the lead veins lying upslope to the west of the spring, but drilling done after the water sampling proved the presence of zinc ore underlying the lead deposits. This zinc ore may be the main source of heavy metals in the spring water.

Beginning about 75 feet southeast of the spring near point $J$, six soil samples were collected on a line running northwest along the south side of the stream. The first sample was taken from the vicinity of several prospect pits (not shown on the map) and contained about 20 times the normal amount of zinc and 10 times the normal amount of lead. The rest of the soil samples contained no more than 2 to 3 times the normal amount of lead or zinc. Thus, it seems probable that the source area of the heavy metals in the spring water south of point $J$ lies to the southeast of the spring. There is a possibility that the lead veins referred to in plate 13 and situated more than 200 feet south of the spring may be the main source of heavy metals, but this does not seem likely owing to the distance from the spring.

The spring at point $K$ has a relatively large flow of water containing heavy metals (believed to be mainly zinc) in a concentration about 35 times background. The flow was estimated at 100 cubic feet per minute and a calculation was made of the amount of zinc being carried away in solution each year. On this basis 1,150 pounds of zinc per year are being removed in solution by the waters issuing from this spring.

At point $N$ the drainage contains unusual quantities of heavy metals, but no lead veins that lie close enough to be an obvious source are mapped, although several prospect pits are shown. A series of 4 soil samples taken about 200 feet upslope to the north of point $N$ showed that the soil contained more than 4 times the normal zinc content and 10 times the normal lead content. Therefore, there must be present at least low-grade mineralized rock which may be responsible for the heavy metals in the water. 
Examination of the map (pl. 12) will show possible causes of the anomalies found in most of the other springs and streams.

\section{PRECIPITATION OF HEAVY METALS FROM SPRING AND STREAM WATER}

One fact that may cause confusion in interpreting the analytical data presented in plate 11 is the precipitation of heavy metals from spring and stream water as the $\mathrm{pH}$ rises. The spring at point $A$ is one example of this loss by precipitation. At the spring the $\mathrm{pH}$ is 7.3 and the heavy-metal content $0.45 \mathrm{ppm}$, but as the water flows toward the main stream, the heavy-metal content decreases and the $\mathrm{pH}$ increases. Similar removal of heavy metals from solution can be noted at other springs in the large drainage basin in which spring $A$ is situated.

The drainage from the spring near point $C$ was examined in detail and the information obtained is shown in figure 31. The concentration of heavy metals decreases most sharply as the $\mathrm{pH}$ is increasing most rapidly, and the concentration of zinc in sediments is greatest where the zinc is precipitating most rapidly from the water. A calculation of the amount of zinc being precipitated, assuming that the heavy metals consist primarily of zinc, shows about 0.013 pound per day, or 0.4 pound per month, if the flow is correctly estimated at 10 cubic feet per hour. From the information available in figure 31, an estimate was made of the total amount of zinc present in the first onehalf inch of silt and organic material in the spring drainage (the onehalf inch figure was chosen because that was about the depth to which the material was removed in sampling). The drainage area was estimated at 575 square feet, the average zinc content at 0.8 percent, and the averagge specific gravity of the material as 1.5. Calculated on the basis of these figures, the amount of zinc present in the spring drainage in the top one-half inch of sediment would be approximately equivalent to that produced by 4 years of precipitation at the rate of 0.4 pound per month. Although all of the data used in reaching this estimate are subject to much error because of variation in the rate of precipitation, loss of zinc in spring floods, and inaccurate estimates of various values used in the calculations, it is quite probable that the present channels have remained relatively unchanged for the last several years, and that the precipitation of zinc from the water is not an unusual, short-term phenomenon.

Correlation of the zinc decrease with the $\mathrm{pH}$ increase should not be taken to indicate that the $\mathrm{pH}$ alone controls the amount of zinc in the water, for some organic material is present in all of the streams and the most rapid loss of heavy metals from solution seems to be related to drainages where much decaying vegetation is present. Certainly, the 


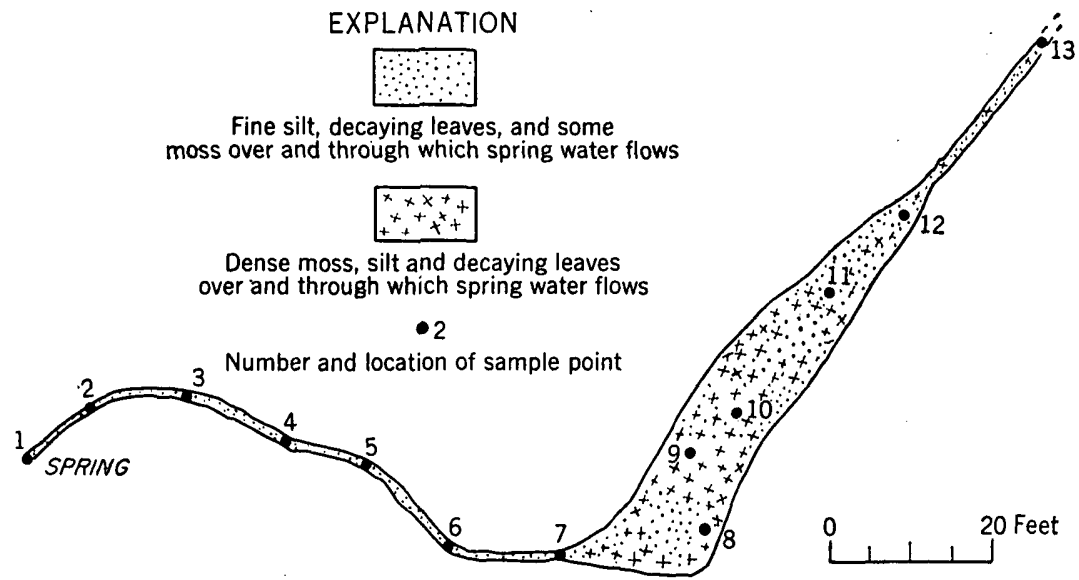

MAP SHOWING SPRING DRAINAGE
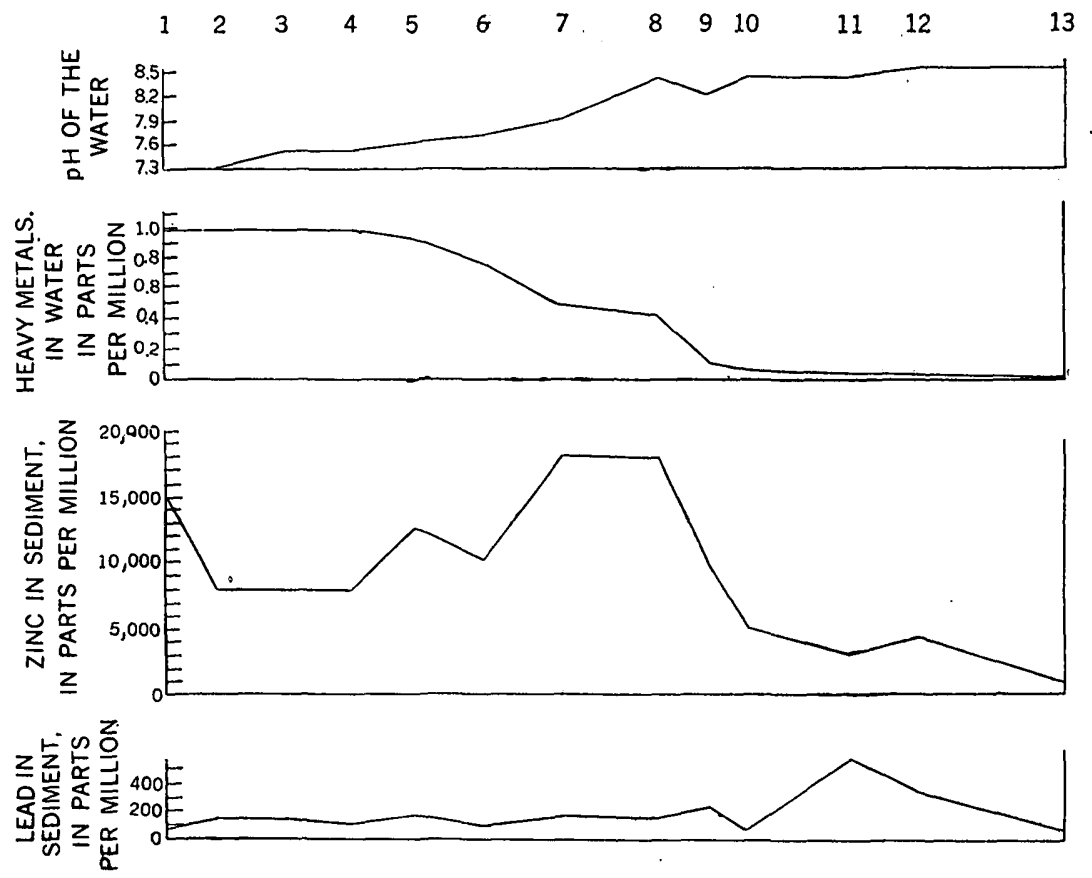

Fiadrn 31.-Precipitation of heavy metals from spring water near Point $\sigma$, Potosi area.

fact that several streams of $\mathrm{pH} 8.3$ contain more than $0.05 \mathrm{ppm}$ heavy metals indicates that the precipitation is not due to $\mathrm{pH}$ alone

\section{SIGNIFICANCE OF THE DATA OBTAINED}

The results of a study of the zinc and lead content of soils, rocks, and waters in the southwestern Wisconsin zinc-lead area indicate that geochemical prospecting techniques can be of value in prospecting 
there. Where the lead and zinc minerals are at or near the water table and are undergoing oxidation and solution, it should be possible to find anomalous amounts of heavy metals in springs nearby or in drill holes down the water-table gradient from the locus of mineralization. Analysis of streams is not so promising as analysis of springs because of the precipitation of heavy metals from streams; however, under certain circumstances, analysis of stream water is helpful. If part of an ore body or a zone of above-normal concentration of zinc and lead associated with an ore body extends to the surface of bedrock, analysis of residual soil will outline the zone of high zinc or lead content.

The possible presence of loess in soil samples must always be considered, and extreme care should be taken to collect residual material. In areas where the loess is only a few inches thick, the mixing of it with the residuum by various natural agencies can be expected, and a gradation from a material consisting mainly of loess to one of essentially all residuum will be found. In such places there may be no clear-cut residual clay layer, and a slight variation in the depth of the sample or in completeness of soil mixing will change the proportions of residuum and loess, with a resultant difference in the significance of the analytical results. Where the loess is several feet thick, there is a gradation from essentially 100 percent loess to almost 100 percent residual material. Regardless of whether the loess is thick or thin a general rule for sampling is to collect the sample from the residual clay zone lying just above the layer of partially decomposed bedrock. If no clear-cut layer of clay is present, there is usually a layer of redbrown stained dolomite particles between the loess and the lightercolored, partially weathered bedrock. A sample of this material is not strictly comparable to one of residual clay, but it may suffice if no clay is present.

The ratio of lead to zinc, even along one mineralized zone, cannot be expected to remain constant. Although lead may be the better indicator of an anomaly at one point in the zone, zinc may be better in another; hence, generally both lead and zinc analyses are recommended in prospecting. However, if one is looking only for outcropping lead veins, only a specific test for lead is necessary.

A sampling distance of 50 feet is satisfactory for general prospecting in areas known to be at least slightly mineralized, but under certain conditions this distance can profitably be changed. On steep hillsides where the trend of the mineralization is at right angles to the direction of slope and where the loess cover is gone and residuum is moving downslope rather rapidly, sampling distances down the slope might well be increased to 100 feet or more. In a similar topographical situation, if the trend of mineralization is parallel to the 
direction of slope and sampling is being done at right angles to the direction of slope, sampling distances of less than 50 feet might be advisable. If the target is a long narrow one on rather flat land, as might be for lead veins on some of the hilltops, the pattern of lead or zinc in the soil would be expected to spread only a little and sampling at 25 -foot intervals would be desirable. In general, a consideration of the expected shape, size, and trend of the mineralized zone and its relation to topography will make it possible to select suitable sampling distances.

In reconnaissance work the sample spacing can be enlarged somewhat but probably should not exceed 100 feet. The fact that the chemical tests are semiquantitative and subject to occasional large errors means that it is desirable to space the samples more closely than would be necessary if the tests were always very accurate.

Areas in the vicinity of past mining activity may be suitable for prospecting because such areas are known to be mineralized and additional ore may be found by geochemical prospecting techniques. Geochemical evidence suggests that at the Demby-Weist property there is at least one additional unprospected lead vein near the known veins. At Crow Branch evidence was found indicating an extension of the mineralized zone about 1,000 feet to the southeast. Also, mineralized zones of economic interest may lie to the west of the main ore zone or to the east of the main ore zone on the east limb of the syncline, as suggested by moderately high concentrations of lead in the soil,

- During the summer of 1952 the Dodgeville Mining Company drilled seven holes in a line across the projected extension of the main Crow Branch ore body and found that, although zinc or lead in minable quantity was not present, the mineralized zone did continue in the direction indicated by the geochemical work.

\section{RECOMMENDED METHODS FOR GEOCHEMICAL PROSPECTING IN WISCONSIN}

Prospecting for lead veins present beneath a cover of loess should be possible by means of soil analysis for lead and zinc. The broad and intense anomaly at the Demby-Weist lead range, the strong anomaly at the Champion and Crawford properties, and the lesser * anomalies in the Crow Branch and Potosi areas all indicate that above normal amounts of lead (and sometimes zinc) may be present. in the soil near lead veins.

Zinc ore bodies, ranging in depth from 1 to about 100 feet below the surface may possibly be detected by the presence of lead and zinc in residual soil derived from weathering of the mineralized rock overlying the ore. Of 4 ore bodies lying at depths of 50 to 100 feet below the surface-at points where soil samples were collected-alk 
were indicated by concentrations of either lead or zinc or both in the residual soil. Of three ore bodies lying at depths of 100 to 150 feet below the surface-at points where soil samples were collected-one gave evidence of its presence by the unusual amount of lead and zinc in the soil. In some places above-normal quantities of lead and zinc were found over mineralized zones which were not of ore grade.

The analysis of spring water should also be of help in prospecting, especially in areas where there has been little or no mining activity. In the Potosi area anomalies were detected in the vicinity of minedout deposits as well as in areas not known to be near lead or zinc deposits. The presence of mining activity in the general vicinity did, however, raise a question as to whether the cause of an anomaly was a previously undiscovered mineralized area or whether it was a deposit which had already been mined. In an undisturbed area the presence of unusually large quantities of heavy metals in spring water would very probably indicate an undiscovered mineralized area. However, if zinc deposits are to be found by the analysis of spring waters, they must be at relatively shallow depths where oxidation and solution of the zinc minerals will be relatively rapid.

The use of stream analysis in prospecting may be of value at times when sampling of the individual springs supplying the stream with water is not feasible. In a few instances the author found that a stream gradually increased in size because of the presence of a great many small springs instead of a few large ones. Under these circumstances the best policy seems to be to sample the larger of the springs and also to sample the stream at regular intervals. In general, however, the fact that heavy metals tend to precipitate from solution shortly after water reaches the land's surface means that sampling should be done at the spring if possible.

\section{SOME METHODS OF PROSPECTING NOT RECOMMENDED}

The analysis of farm wells for heavy metals as a means of prospecting is not promising nor is the analysis of water from drill holes promising in areas where the ore-bearing horizons are more than 100 feet below the water table. Because of the oxidation and solution of the zinc from galvanized pipes, the water from farm wells is relatively high in total content of heavy metals and the small amount of zinc which might be derived from an ore body nearby cannot be distinguished from that derived from a galvanized pipe. Although, under favorable circumstances, it may be possible to obtain anomalous quantities of heavy metals in ground water near ore bodies lying more than 100 feet below the water table, this is not a promising method of prospecting for general use. 


\section{SOME UNSOLVED PROBLEMS}

As in much research, problems developed which were not solved. Some of these should be studied before serious prospecting is done, and others are not of such immediate importance.

Before extensive prospecting for lead veins can be done, some experimentation with rapid methods of collecting the sample should be performed. A power auger probably would serve the purpose, but no equipment of this type has been tried by the author. It is known that augering by hand in deep loess would be prohibitively expensive in time and effort.

The frequency with which primary halos of the type found at Crow Branch may be expected above zinc ore bodies has not been determined. That such a primary halo commonly is present is indicated by the results over the five ore bodies which were studied. The dependability of this phenomenon should be established before any conclusions regarding its usefulness in prospecting can be drawn. Furthermore, many more ore bodies must be studied before any definite conclusion can be reached about the vertical and horizontal dimensions of the primary halos.

No effort was made to determine what elements other than lead, zinc, and iron are disseminated near ore bodies, but such a study seems desirable. Unusually large quantities of chert were found in the residual soil overlying the North Dodgeville, South Dodgeville, and Crow Branch ore bodies. This suggests silica as being part of a primary halo. The presence of much chert may not necessarily mean mineralization, for there are certain beds which contain concentrations of chert and these, when weathered, produce cherty soils. Nevertheless, in the three areas mentioned, the soil not lying over the mineralized zones showed little or no chert, but the soil over the ore contained so much chert that hand augering was difficult, and, in a few instances, impossible.

In only one instance were water samples collected from drill holes bored near an ore body lying close to the water table (drill holes 6-8, pl. 17). The oxidation and solution of the disseminated ore minerals in the vicinity of the ore probably produced the abovenormal concentrations of heavy metals in ground water. This, if common, could be very useful in prospecting for shallow ore bodies. Sufficient work has not been done, however, to determine in any detail what the relation of the ore body to the water table must be in order. to produce such anomalies.

Many more problems could be stated, but the author believes that the solution of the ones listed above would provide much help in prospecting by geochemical methods. 


\section{CONCLUSIONS}

Geochemical methods of prospecting show definite promise as a tool for the geologist searching for ore deposits in southwestern Wisconsin. The data obtained by analyzing natural soils, rocks, and waters in the vicinity of known ore indicate that there are abnormally high concentrations of lead, zinc, and iron present in these materials near hidden ore deposits. Although further research seems necessary before geochemical techniques can be used to the fullest advantage, the information obtained thus far should be of help in prospecting at the present time.

\section{LITERATURE CITED}

Almond, Hy, and Morris, H. T., 1951, Geochemical techniques as applied in recent investigations in the Tintic district, Utah: Econ. Geology, จ. 46, no. 6, p. 608-625.

Bean, E. F., 1949, Geologic map of Wisconsin: Wis. Geol. and Nat. Hist. Survey, 1 map.

Behre, C. H., Jr., Heyl, A. V., Jr., and McKnight, E. T., 1948, Zinc and lead deposits of the Mississippi Valley : 18th Internat. Geol. Cong., Rept. 18th Sess., pt. 7, p. 61-69, London [1950].

Behre, C. H., Jr., Scott, E. R., and Banfleld, A. F., 1937, The Wisconsin lead-zinc district, preliminary paper : Econ. Geology, v. 32, p. 783-809.

Chamberlin, T. C., 1897, Supplementary hypothesis respecting the origin of the loess of the Mississippi Valley : Jour. Geology, v. 5, p. 795-802.

Hall, James, and Whitney, J. D., 1862, The geology of Wisconsin: Wisconsin Geol. Survey, v. 1.

Harbaugh, J. W., 1953, Geochemical prospecting abstracts through June 1952: U. S. Geol. Survey Bull. 1000-A.

Hawkes, H. E., 1950, Geochemical prospecting for ores, in Trask, P. D., Applied sedimentation, p. 537-555, New York, John Wiley and Sons.

Heyl, A. V., Jr., Lyons, E. J., and Agnew, A. F., 1948, Geologic structure map of the Potosi lead-zinc area, Grant County, Wis.: U. S. Geol. Survey Strategic Minerals Invest. Prelim. Map 3-221, 1 map.

1951, Exploratory drilling in the Prairie du Chien group of the Wisconsin zinc-lead district by the U. S. Geol. Survey in 1949-1950: O. S. Geol. Survey Circ. 131, p. 7-9, 17-22.

Heyl, A. V., Jr., Lyons, E. J., Agnew, A. F., and Behre, C. H., Jr., 1955, Zinc, lead, copper resources and general geology of the Upper Mississippi Valley district: U. S. Geol. Survey, Bull. 1015-G.

Hole. F. D., 1950. Areas having aeolian silt and sand deposits in Wisconsin: Soils Div., Wis. Geol. and Nat. Hist. Survey, 1 map.

Holmes, R. S., 1945, Determination of total copper, zinc, cobalt, and lead in soil and soil solutions: Soil Science, v. 59, p. 77-84.

Huff, L. C., 1948, A sensitive field test for heavy metals in water : Econ. Geology, v. 43 , no. 8 , p. $675-684$.

- 1951, A sensitive fleld test for detecting heavy metals in soil or sediment: Econ. Geology, v. 46, no. 5, p. 524-540. 
Lakin, H. W., Almond, Hy, and Ward, F. N., 1952, Compilation of field methods used in geochemical prospecting by the U. S. Geological Survey : U. S. Geol. Survey Circ. 161.

Lakin, H. W., Stevens, R. E., and Almond, Hy, 1949, Field method for determination of zinc in soils: Econ. Geology, v. 44, no. 4, p. 296-306.

Sandell, E. B., 1944, Colorimetric determination of traces of metals : New York, Interscience Publishers, Inc.

Smith, G. D., 1942, Illinois loess-variations in its properties and distribution: Illinois Univ. Agr. Exper. Sta. Bull. 490.

Anonymous, 1955, American zinc active in Wisconsin: Skillings Mining Revlew, v. 44 , no. 3 , p. 8. 



\section{INDEX}

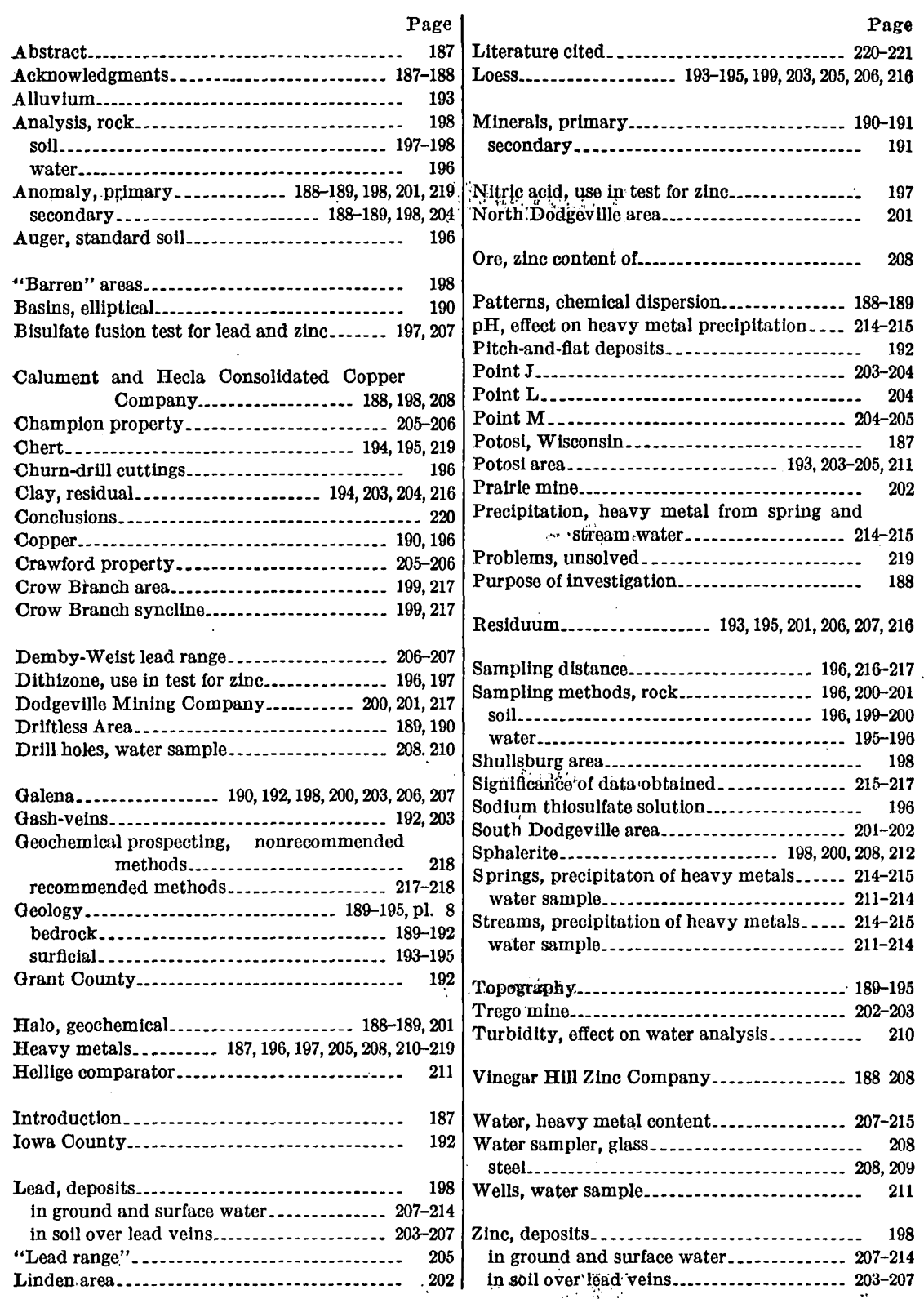

